\title{
PENGARUH KREATIVITAS TERHADAP KEBERHASILAN USAHA PADA USAHA MIKRO KECIL MENENGAH (UMKM) DI DESA PATUMBAK KAMPUNG KECAMATAN PATUMBAK KABUPATEN DELI SERDANG
}

\author{
Soriyani Harahap, Nur'ain Harahap \\ Fakultas Ekonomi, Universitas Muslim Nusantara Al Washliyah, Program Studi Manajemen \\ Email: yanieharahap04@gmail.com
}

\begin{abstract}
To determine the effect of creativity on business success in Small and Medium Enterprise (SME) in Patumbak Village, Patumbak Village, Patumbak District, Deli Serdang Regency is the purpose of this research. By taking a sample of 60 respondents Micro, Small and Medium Enterprise (SME) in Patumbak Village. This research uses a quantitative descriptive method by distributing questionnaires. The results showed that creativity had an effect on business success in micro, Small and Medium Enterprise (SME) in Patumbak Village, Patumbak Subdistrict, Deli Serdang Regency. It can be concluded that the better and the higher the level of creativity applied in the business, the success of the business will also increase.
\end{abstract}

Keywords: creativity, SME business success

\section{Abstrak}

Untuk mengetahui pengaruh kreativitas pada keberhasilan usaha mikro kecil menengah (UMKM) di Desa Patumbak Kampung Kecamatan Patumbak Kabupaten Deli Serdang merupakan tujuan dari riset ini. Dengan mengambil sampel sebanyak 60 responden Usaha Mikro Kecil Menengah (UMKM) di Desa Patumbak. Riset ini menggunakan metode desktiptif kuantitatif dengan cara menyebar kuesioner. Hasil penelitian didapatkan bahwa bahwa kreativitas berpengaruh terhadap keberhasilan usaha pada usaha mikro kecil menengah (UMKM) di Desa Patumbak Kampung Kecamatan Patumbak Kabupaten Deli Serdang. Dapat disimpulkan bahwa semakin baik dan semakin tinggi tingkat kreativitas yang diterapkan di dalam usaha, maka keberhasilan usaha akan semakin meningkat juga.

Kata kunci: kreativitas, keberhasilan usaha UMKM

\section{Pendahuluan}

UMKM juga tidak terlepas dari pemikiran kreatif setiap pelaku bisnis untuk membuat bidang usaha baru dan mendorong para wirausaha untuk berperan aktif mengkreasikan kemampuan yang ada untuk tercapainya keberhasilan usaha yang signifikan, serta bisa dipergunakan oleh pemerintah sebagai salah satu pijakan dalam mengambil strategi dan aturan yang menopang keberhasilan usaha kecil di Patumbak Kampung Kabupaten Deli Serdang.Patumbak Kampung merupakan daerah yang banyak ditemukan pelaku Usaha Mikro Kecil Menengah sebanyak 120 UMKM yang beroperasi seperti UMKM tukang jahit, warung kopi, kerajinan tangan, peternak, kounter ponsel, rumah makan, 


\section{Vol. 2 No. 2 Bulan Oktober2021-Maret 2022}

salon, makanan ringan, yang di produksi oleh ibu rumah tangga.

Kreativitas memainkan peran penting dalam mempertahankan bisnis/usaha. Banyak sekali kemenangan yang didapatkan oleh para pebisnis berawal dari kecerdikan mereka dalam melacak perkembangan produk bisnis mereka. Bentuk kreativitas ini harus didasarkan pada pemikiran mutakhir, pemikiran baru, dan tidak serupa dengan yang beredar. Dengan asumsi seorang visioner bisnis dapat mengembangkan kreativitas untuk pencapaian bisnisnya, maka, pada saat itu, bisnis yang diawasi juga dapat terlihat berbeda dibandingkan dengan organisasi sejenis lainnya.

kreativitas adalah kapasitas untuk menumbuhkan pemikiran baru dan untuk melacak pendekatan yang lebih baik untuk memeriksa masalah dan memantau kesempatan usaha. Mendirikan bisnis tidak sesederhana yang dipikirkan, karena kegiatan bisnis akan menghadapi kesulitan, terutama dalam melacak hal-hal inovatif terbaru. Untuk situasi ini, para pelaku bisnis saat ini memiliki cara tersendiri dalam mengelolanya dan sampai saat ini mereka yang bertahan memiliki ide untuk mengambil keputusan dengan mentolerir analisis dan ide dari pembeli. Prestasi dalam bisnis juga memiliki nilai estimasi yang mencakup pencapaian tujuan dalam bisnis, produk yang diakui pasar, produksi yang bermanfaat, terpenuhinya laba, kepuasan tersendiri dalam menjalankan usahanya. Seorang individu yang mempertahankan bisnis harus memiliki tujuan mereka sendiri, yang secara umum adalah menghasilkan keuntungan. Mereka menciptakan keuntungan, untuk pemenuhan kebutuhannya karena apa yang mereka jual dapat diakui oleh pasar dan dari penjualan mendapatkan laba yang memenuhi keperluan mereka.

Permodalan tercukupi, penyaluran usaha telah produktif dan tujuan organisasi telah tercapai merupakan defenisi dari keberhasilan usaha . Menurut data pendapatan yang diperoleh dari UMKM Patumbak Kampung setiap bulannya dari bulan April - Juni 2021, terjadi penurunan pendapatan yang cukup drastis setiap bulannya selain itu penurunan jumlah karyawan atau tenaga kerja dan pengusaha di Patumbak Kampung lebih cendrung fluktuatif setiap tahunnya.Dari 120 UMKM yang ada di data hanya sekitar 60 UMKM yang masih aktif.Hal ini menandakan terjadinya penurunan keberhasilan usaha.

Berdasarkan wawancara yang dilakukan peneliti, banyak faktor yang mempengaruhi hal tersebut, diantaranya karena kreaivitas yang kurang dapat dikembangkan pada produk-produk yang dipasarkan. Fenomena yang terjadi di 


\section{Vol. 2 No. 2 Bulan Oktober2021-Maret 2022}

patumbak kampung bahwa para UMKM kurang kreatif dimana masih terlihat para umkm tidak memiliki idi kreatif yang luas. Para UMKM juga belum mempunyai wawasan yang luas untuk mengembangkan produk baru sehingga sulit untuk mencapai keberhasilan usaha serta UMKM sering terjadi penurunan dalam melakukan produksi produknya mengakibatkan para UMKM mendapatkan keuntungan yang tidak sesuai dengan target dan terjadilah penurunan pendapatan setiap tahunnya.

\section{Tinjauan Pustaka}

Kreativitas dapat diaktakan sebagai salah satu keperluan utama manusia, yaitu keperluan akan aktualisasi diri serta merupakan keperluan tertinggi untuk manusia. seyogyanya setiap orang lahir di muka bumi ini dengan membawa potensi kreatif. Kreativitas bisa dilihat dan dipupuk melalui jalur menuntut ilmu yang tepat. Supriadi (2017) mengemukakan bahwa kreativitas yaitu kecakapan individu untuk menciptakan penemuan baru yang dapat berbentuk ide maupun ciptaan nyata yang terbaru tidak mirip dengan yang banyak beredar umum. Selain itu juga kreativitas dapat diilustrasikan sebagai keahlian berpikir hebat yang memperaktikkan terjadinya peralihan dalam berfikir. Putranta (2017) menyebutkan bahwa kemajuan bisnis dapat ditinjau dari ketepatanguna dalam proses produksi yang dihimpunkan bersumber dari ketepatan secara teknis dan ketepatan secara ekonomis.

$$
\text { Selanjutnya Suyatno }
$$
pencapaian/keberhasilan usaha modern kecil dipengaruhi oleh variabel yang berbeda. Kinerja bisnis organisasi merupakan salah satu tujuan dari setiap visioner bisnis. Kinerja organisasi modern kecil dapat diuraikan sebagai tingkat pencapaian dalam mencapai tujuan atau sasaran yang normal. Selain tingkat pencapaian dari segi laba, keberhasilan bisnis/usaha dapat ditinjau dari sasaran yang telah direncanakan.

Hal ini sebagaimana diungkapkan oleh Dalimunthe dalam Edi Noersasongko (2005) yang menyebutkan bahwa keberhasilan suatu usaha dapat dianalisa dengan mengetahui suatu perusahaan yang dapat diperoleh dari perbandingan nilai yang diharapkan dengan memanfaatkan sumber daya yang tersedia. Kemampuan hasil kerja perusahaan merupakan output dari banyak indikator di atas, oleh karena itu ukuran ini sangat diperlukan dalam menentukan tingkat adaptasi bisnis terhadap lingkungannya. Kinerja menjadi tolak ukur dalam memeberikan penilaian tentang ukuran besar kecilnya persaingan yang menjadi capaian usaha atau bisnis 


\section{Metode Penelitian}

Metode yang dipergunakan untuk riset ini yaitu teknik deskriptif kuantitatif. Riset dilaksanakan di Desa Patumbak, Kecamatan Patumbak, Kabupaten Deli Serdang. Bermacam-macam informasi dalam review ini diperoleh melalui observasi dan kuesioner. responden dalam riset ini adalah masyarakat sekitar yang memiliki usaha kecil menengah (UMKM) di Desa Patumbak Kampung. sampel menggunakan teknik Random Sampling, yang diambil dari responden secara acak tidak mengindahkan strata yang ada dalam populasi. Sampel yang diperoleh sebanyak 60 responden. Untuk menentukan pengaruh variabel bebas dan variabel terikat, persamaan dapat di tuliskan dengan $\mathrm{Y}=3,197+0,393 \mathrm{X}$

Adapun kerangka konseptual penelitian ini dapat diilustrasikan seperti gambar di bawah:

\begin{tabular}{|c|} 
Kreativitas \\
$(\mathrm{X})$
\end{tabular}$\longrightarrow \begin{gathered}\text { Keberhasilan } \\
\text { usaha }(\mathrm{Y})\end{gathered}$

\section{Gambar 1. kerangka konseptual}

Didasarkan pada gambar di atas dapat ditentukan bahwa hipotesis dalam riset ini yaitu $\mathrm{H}_{0}=$ Diduga tidak ada pengaruh kreativitas kepada keberhasilan Usaha Mikro Kecil Menengah (UMKM) di Desa Patumbak Kampung Kecamatan
Patumbak Kabupaten Deli Serdang. Ha = Diduga ada pengaruh kreativitas kepada keberhasilan usaha mikro kecil menengah (UMKM) di Desa Patumbak Kampung Kecamatan Patumbak Kabupaten Deli Serdang.

\section{Hasil Penelitian dan Pembahasan}

\subsection{Hasil Penelitian}

\section{Uji Validitas}

Validitas menunjukkan sejauh mana instrumen dipergunakan dalam menghitung apa yang diestimasi. Uji validitas mengemukakan bahwa alat ukur yang dipergunakan untuk memperoleh informasi dalam penelitian dapat dimanfaatkan atau tidak. kuesioner yang dipergunakan dalam riset ini dicoba untuk uji validitasnya dan reliabilitasnya sebelum dipergunakan sebagai perangkat pengumpulan informasi. Hasil uji validitas dapat di lihat di tabel berikut:

Tabel. 1 Hasil Uji Validitas kreativitas (X)

\begin{tabular}{|l|c|l|c|}
\hline No Pernyataan & $\begin{array}{c}\text { Corrected Item- Total } \\
\text { Correlation }\end{array}$ & $\mathbf{r}_{\text {tabel }}$ & Status \\
\hline Pernyataan 1 & 0.565 & 0,374 & Valid \\
\hline Pernyataan 2 & 0.465 & 0,374 & Valid \\
\hline Pernyataan 3 & 0.424 & 0,374 & Valid \\
\hline Pernyataan 4 & 0.397 & 0,374 & Valid \\
\hline Pernyataan 5 & 0.772 & 0,374 & Valid \\
\hline Pernyataan 6 & 0.450 & 0,374 & Valid \\
\hline
\end{tabular}

Sumber: Peneliti olah (2021) 
Variabel kreativitas (X) diukur dengan mempergunakan kuesioner terangkum didalamnya 6 pernyataan. berlandaskan keluaran telaah korelasi product moment yang sudah dilaksanakan terhadap angket itu. Keluaran diperoleh dari angka Corrected Total Corelation $>\mathrm{r}$ rabel $(\mathrm{df}$ $=30-2=28$ ) sebesar 0,374. Karenakan angka itu > dari 0,374 maka tiap-tiap kuesioner memadai djadikan penilai variabel kreativitas.

Tabel 2. Hasil Uji Validitas keberhasilan usaha $(\mathbf{Y})$

\begin{tabular}{|l|c|c|c|}
\hline No Pernyataan & $\begin{array}{c}\text { Corrected Item- Total } \\
\text { Correlation }\end{array}$ & $\mathbf{r}_{\text {table }}$ & Status \\
\hline Pernyataan 1 & 0.538 & 0,374 & Valid \\
\hline Pernyataan 2 & 0.409 & 0,374 & Valid \\
\hline Pernyataan 3 & 0.401 & 0,374 & Valid \\
\hline
\end{tabular}

Sumber: Peneliti olah (2021)

Variabel Keberhasilan usaha (Y) dinilai dengan memanfaatkan kuesioner berupas 3 pernyataan. Didasarkan pada hasil analissi korelasi product moment yang sudah dilaksanakan pada kuesioner tersebut diperoleh angka Corrected Total Corelation $>\mathrm{r}_{\text {rabel }}(\mathrm{df}=30-2=28)$ sebesar 0,374. Oleh sebab itu, angka tersebut > dari 0,374 dan tiap-tiap angket memadai dilakukan pada angket penilai variabel keberhasilan usaha.

\section{Uji Reliabilitas}

Keluaran Uji reliabilitas pada angket penilai variabel penelitian memakai metode Alpha-Cronbach tertera pada tabel berikut ini:

Tabel. 3 Hasil Uji Reliabilitas

\begin{tabular}{|c|l|c|c|}
\hline No & \multicolumn{1}{|c|}{ Variabel } & Alpha-Cronbach & Keterangan \\
\hline 1 & Kreativitas & 0.763 & Reliabel \\
\hline 2 & Keberhasilan usaha & 0.616 & Reliabel \\
\hline
\end{tabular}

Sumber: Peneliti olah (2021)

Didasarkan pada hasil uji reliabilitas pada tiap-tiap kusioner penilai variabel riset di atas tertera bahwa, tiap-tiap angket memperoleh angka Alpha-Cronbach > 0,60 untuk itu selanjutnya dapat dirangkum bahwa angket yang dipergunakan pada riset ini dikategorikan reliabel.

\section{Uji Normalitas Data}

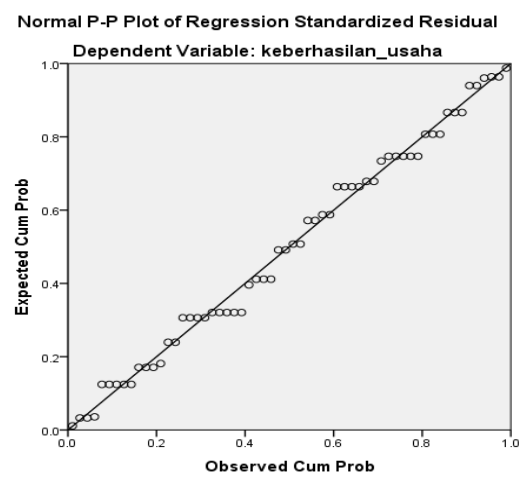

\section{Gambar 2. Hasil Uji Normalitas Data}

Sumber : Hasil Pengolahan Data SPSS, tahun 2021

Dari manifestas grafik uji normalitas, dapat dipastikan bahwa diagram memperlihatkan bahwa model regresi dapat 
Vol. 2 No. 2 Bulan Oktober2021-Maret 2022

dikatakan normal karena pada kebiasaanya titik-titik edar berfokus menyebar di sekitar garis miring.

\section{Uji Regresi Linear}

Dari keluaran sebaran angket yang terdiri 60 sampel responden penulis menyarikan keluaran analisis regresi sederhana dengan angka konstanta 3,197 mengemukakan kreativitas akan tetap sebesar 3,197 jika tidak dipengaruhi variabel keberhasilan usaha dan angka koefisien regresi sebesar 0,393 yang memiliki makna tiap kreativitas mempengaruhi keberhasilan usaha sebesar 39,3\%. Apabila kreativitas ditingkatkan 1\% maka keberhasilan usaha ikut meningkat sebesar 39,3\% dengan (asumsi faktor lain tetap).

\section{Uji Hipotesis}

Tabel. 4 Hasil Uji t

\begin{tabular}{|c|c|c|c|c|c|}
\hline \multicolumn{6}{|c|}{ Coefficients ${ }^{\mathrm{a}}$} \\
\hline \multirow[b]{2}{*}{ Model } & \multicolumn{2}{|c|}{$\begin{array}{l}\text { Unstandardized } \\
\text { Coefficients }\end{array}$} & \multirow{2}{*}{$\begin{array}{c}\text { Standardized } \\
\text { Coefficients } \\
\text { Beta }\end{array}$} & \multirow[b]{2}{*}{$t$} & \multirow[b]{2}{*}{ Sig. } \\
\hline & B & Std. Error & & & \\
\hline (Constant) & 3.197 & 1.244 & & 2.570 & .013 \\
\hline kreativitas & .393 & .050 & .719 & 7.888 & .000 \\
\hline
\end{tabular}

Sumber : Data diolah tahun 2021

Didasarkan pada hasil keluaran tabel Uji t pada variabel independent dinyatakan bahwa kreativitas (X) memiliki pengaruh positif dan signifikan pada keberhasilan usaha didapati nilai $t_{\text {hitung }}=7,888>1,67$ dan probabilitas 0,000 pada ukuran signifikansi $5 \%$. Keadaan ini menunjukkan makin baiknya kreativitas yang dipunya, maka keberhasilan usaha mikro kecil menengah (UMKM) di Desa Patumbak Kampung Kecamatan Patumbak Kabupaten Deli Serdang makin naik.

\section{Uji Koefisien Determinasi (R Square)}

Hasil uji koefisien determinasi disarikan pada tabel berikut:

\section{Tabel 5. Uji R square}

\begin{tabular}{|l|c|c|c|c|}
\hline \multicolumn{5}{|c|}{ Model Summary $^{\mathrm{b}}$} \\
\hline Model & $\mathrm{R}$ & $\mathrm{R}$ Square & $\begin{array}{c}\text { Adjusted R } \\
\text { Square }\end{array}$ & $\begin{array}{c}\text { Std. Error of the } \\
\text { Estimate }\end{array}$ \\
\hline 1 & $.719^{\mathrm{a}}$ & .518 & .509 & .884 \\
\hline \multicolumn{5}{|l|}{ a. Predictors: (Constant), kreativitas } \\
\hline
\end{tabular}

Sumber : Data diolah tahun 2021

Didasarkan pada keluaran SPSS maka perhitungan tabel Koefisien Determinasi $\left(\mathrm{R}^{2}\right)$ didapati angka $\mathrm{R}$ Square sebesar 0,518 atau setara dengan dengan $51,8 \%$. Yang dapat dimaknai model analisis yang dipergunakan bisa menerangkan sebesar 51,8\%, sedangkan sisanya 48,2\% dipengaruhi oleh faktor lain yang tidak termasuk dalam penelitian.

\subsection{Pembahasan}

Setelah menganalisis jawaban dari setiap kuesioner yang diperoleh dari 60 responden, maka dilanjutkan dengan menguji hipotesis. Dengan hipotesa yang diajukan, diharapkan dapat menunjukkan sejauh mana pengaruh kreativitas terhadap keberhasilan 


\section{Vol. 2 No. 2 Bulan Oktober2021-Maret 2022}

usaha pada usaha mikro kecil menengah (UMKM) di Desa Patumbak Kampung Kecamatan Patumbak Kabupaten Deli Serdang.

$\begin{array}{rll}\text { Hasil } & \text { jawaban } 60 & \text { responden } \\ \text { berdasarkan } & \text { karakteristik } & \text { responden }\end{array}$
diperoleh bahwa responden dalam penelitian ini mayoritas adalah laki-laki yaitu 34 orang dari dan responden perempuan berjumlah 26 orang. Maka dapat disimpulkan bahwa responden berdasarkan jenis kelamin, pelaku usaha mikro kecil menengah (UMKM) di Desa Patumbak Kampung Kecamatan Patumbak Kabupaten Deli Serdang, paling dominan berjenis kelamin laki laki yaitu sebanyak 34 orang atau sebesar 57\%.

$$
\text { Pada hasil analisis deskriptif }
$$

karakteristik responden responden berdasarkan usia 26-36 adalah 20 orang atau sebesar 33\%, usia 37-47 adalah 23 orang atau sebesar 39\% dan usia 48-58 adalah 17 orang atau sebesar 28\%. Maka dapat disimpulkan dari tabel diatas bahwa responden berdasarkan usia, pelaku usaha UMKM pada Desa Patumbak Kampung kecamatan Patumbak yang paling dominan adalah pada usia 37-47 yaitu sebesar 23 responden atau sebesar $39 \%$.

Berdasarkan hasil regresi linear sederhana $\mathrm{Y}=3,197+0,393 \mathrm{X}$ dengan nilai Konstanta sebesar 3,197 menyatakan bahwa kreativitas akan konstan sebesar 3,197 jika tidak dipengaruhi variabel keberhasilan usaha dan nilai koefisien regresi sebesar 0,393 berarti setiap kreativitas mempengaruhi keberhasilan usaha sebesar 39,3\% artinya jika kreativitas ditingkatkan $1 \%$ maka keberhasilan usaha akan meningkat sebesar 39,3\% dengan (asumsi faktor lain tetap).

Uji $\mathrm{t}$ untuk variabel independent adalah bahwa kreativitas (X) berpengaruh positif dan signifikan terhadap keberhasilan usaha dengan nilai $t_{\text {hitung }}=7,888>1,67$ dan probabilitas 0,000 pada tingkat signifikansi $5 \%$. Hal ini berarti semakin baik kreativitas yang dimiliki, maka keberhasilan usaha pada usaha mikro kecil menengah (UMKM) di Desa Patumbak Kampung Kecamatan Patumbak Kabupaten Deli Serdang semakin meningkat. Nilai R Square sebesar 0,518 atau sama dengan 51,8\%. Berarti model analisis yang digunakan mampu menjelaskan sebesar $51,8 \%$. Menurut tingkat interpretasi diketahui besarnya pengaruh kreativitas terhadap keberhasilan usaha pada usaha mikro kecil menengah (UMKM) di Desa Patumbak Kampung Kecamatan Patumbak Kabupaten Deli Serdang berada pada kategori sedang, sedangkan sisanya 48,2\% dipengaruhi oleh faktor lain yang tidak diteliti. Didukung dengan penelitian 


\section{Vol. 2 No. 2 Bulan Oktober2021-Maret 2022}

terdahulu oleh peneliti Alkachi, dkk (2019) dengan judul penelitian kreativitas inovasi produk terhadap kebehasian usaha (survey pada pengusaha sentra sangkar burung sukahaji Bandung), dengan hasil penelitian menunjukkan bahwa kreativitas dan inovasi produk pentinh untuk kesuksesan bisnis. Dengan uji hipotesis membuktikan adanya perbedaan kreativitas dan inovasi produk terhadap keberhasilan bisnis secara parsial maupun simultan. Didukung juga dengan dengan penelitian yang dilakukan oleh Sumardhi (2018) dengan judul penelitian pengaruh karakteristik wirausaha terhadap keberhasilan uasaha pedagang etnis jawa dan cina hasil penelitian berdasarkan menemukan bahwa karakteristik wirausaha mempunyai pengaruh signifikan terhadap keberhasilan usaha, dengan nilai alpa=0,000<0,05. Hasil uji beda menemukan bahwa tidak ada perbedaan keberhasilan usaha etnis jawa, terbukti dengan nilai t sebesar 0,291 dengan tingkat signifikansi sebesar 0,772 >0,05. Hal ini memberikan gambaran bahwa tingkat keberhasilan berwirausaha antara etnis cina dengan etnis jawa adalah tidak sama, selain itu ada beberapa peneliti lain yang ikut meneliti dengan topik yang sama dengan hasil yang sama pula yaitu hadiyati (2011), purwanti (2012), Sarijani (2014) serta sumardi dan zulpendi (2017)

\section{Kesimpulan dan Saran}

\subsection{Kesimpulan:}

Berdasarkan hasil penelitian dan pembahasan maka dapat disimpulkan bahwa:

1. Kreativitas memberikan kontribusi secara signifikan terhadap keberhasilan usaha. adapaun pengaruh yang signifikan tersebut memiliki makna semakin baik dan meningkatnya kreativitas yang diberikan untuk usaha, maka keberhasilan usaha akan semakin meningkat.

2. Keluaran dari penelitian ini menyatakan bahwa menyatakan bahwa kreativitas berpengaruh terhadap keberhasilan usaha pada usaha mikro kecil menengah (UMKM) di Desa Patumbak Kampung Kecamatan Patumbak Kabupaten Deli Serdang dengan hasil regresi sederhana $\mathrm{Y}=3,197+0,393 \mathrm{X}$ dengan nilai Konstanta sebesar 3,197 menyatakan bahwa kreativitas akan konstan sebesar 3,197 jika tidak dipengaruhi variabel keberhasilan usaha dan nilai koefisien regresi sebesar 0,393 berarti setiap kreativitas mempengaruhi keberhasilan usaha sebesar 39,3\% artinya jika kreativitas ditingkatkan $1 \%$ maka keberhasilan usaha akan meningkat sebesar 39,3\% dengan (asumsi faktor lain tetap). 


\section{Vol. 2 No. 2 Bulan Oktober2021-Maret 2022}

3. Uji t untuk variabel independent adalah bahwa kreativitas (X) berpengaruh positif dan signifikan terhadap keberhasilan usaha dengan nilai $t_{\text {hitung }}=$ 7,888 > 1,67 dan probabilitas 0,000 pada tingkat signifikansi 5\%. Hal ini berarti semakin baik kreativitas yang dipunyai, maka keberhasilan usaha pada usaha mikro kecil menengah (UMKM) di Desa Patumbak Kampung Kecamatan Patumbak Kabupaten Deli Serdang semakin meningkat.

4. Nilai R Square sebesar 0,518 atau senilai dengan 51,8\%. Berarti model analisis yang digunakan mampu menjelaskan sebesar 51,8\%, sedangkan sisanya $48,2 \%$ tidak diteliti di penelitian ini karena merupakan faktor lain.

\subsection{Saran}

Saran yang dapat di rangkumkan oleh penulis pada riset ini adalah:

a. Sebaiknya sering diadakan penyuluhan kepada UMKM untuk meningkatkan kreativitas dikalangan pelaku UMKM baik dari pihak pemerintah maupun pihak akademisi

b. Digalakkannya bantuan-bantuan kepada pelaku UMKM baik segi materil dan non materil

\section{DAFTAR PUSTAKA}

Alkachvi, Muhamad Desky, Trustorini, Handayani.2019. Pengaruh Kreativitas Dan Inovasi Produk Terhadap Keberhasilan Usaha (Survey Pada Pengusaha Sentra Sangkar Burung Sukahaji Bandung). Skripsi Program Studi Manajemen Fakultas Ekonomi Dan Bisnis. 1-14

Edi Noersasongko. 2005. Analisis Pengaruh Karakteristik Individu, Kewirausahaan dan Gaya Kepemimpinan Terhadap Kemampuan Usaha Serta Keberhasilan Usaha Pada Usaha Kecil Batik di Jawa Tengah. Skripsi. Malang. Program Pascasarjana Universitas Merdeka Malang.

Hadiyati, Ernani. 2011.Kreativitas Dan Inovasi Berpengaruh Terhadap Kewirausahaan Usaha Kecil. Jurnal Manajemen Dan Kewirausahaan. Vol 13 No $18-16$

Purwanti, E. 2012. Pengaruh Karakteristik Wirausaha, Modal Usaha, Dan Strategi Pemasaran Terhadap Keberhasilan Umkm Di Desa Dayaan Dan Kalilondo Salatiga. Jurnal Ilmiah Among Makarti Vol 5 No 9 13-28

Sarijani, Endang.2014.Peran Kreativitas Dan Inovasi Pelaku Usaha Dalam Diversifikasi Produk Kuliner Pada Kedai Steak \& Chicken Di Kab. Magetan.

Sumardhi, Anik .2018.Pengaruh Karakteristik Wirausaha Terhadap Keberhasilan Usaha Pedagang Etnis Cina Dan Jawa. Jurnal Ilmu dan Riset Manajemen Vol 1 No 1

Sumardi Dan Zulpahmi. 2017. Peran Baitul 
Vol. 2 No. 2 Bulan Oktober2021-Maret 2022

Maal Wat Tamwil Husnayain Terhadap Keberhasilan Usaha Mikro Kecil Menengah. Jurnal Ekonomi Syariah Dan Filantropi Islam Vol 1 No 1

Supriyadi, D. 2017. Kreativitas, Kebudayaan Dan Keberhasilan Iptek. Bandung: Alfabeta

Suryana, Dkk. 2015. Kewirausahaan, Pedoman Praktis, Kiat Dan Proses Menunju Sukses, Edisi Revisi, Jakarta: Salemba Empat.

Suyatno Purnama, Chamdan. 2010. Motivasi dan Kemampuan Usaha Dalam meningkatkan Keberhasilan Usaha Industri Kecil (Studi Pada Industri Kecil Sepatu di Jawa Timur). Jurnal Manajemen dan Kewirausahaan, pp. 177-184. 